\title{
«WHY DEVERBAL NOUNS RATHER THAN FINITE VERBS?» A SEMANTIC-PRAGMATIC CASE-STUDY IN SPANISH AND PORTUGUESE
}

\begin{abstract}
A bstract. Danler Paul, "Why deverbal noths rather than finite verbs?» A semantic-pragmatic case-study in Spanish and Portuguese. Studia Romanica Posnaniensia, Adam Mickiewicz University Press, Poznani, vol. XXXl: 2004, pp. 215-224. ISBN 83-232-1353-4, ISSN 0137-2475.

This paper focusses on a) the qualitative difference between actamts depending on verbs and actants required by nouns and $b$ ) the question whether it might be primarily pragmatic rather than stylistic reasons which account for the preference of deverbal nouns over fimite verbs in certain contexts. Political speeches by Franco and Salazar provide us with challenging corpora for our analysis.
\end{abstract}

\section{INTRODUCTION}

Why would a speaker resort to deverbal nominal constructions rather than to verbal ones, if it is true, as is often claimed ( $c f$. Luidtke. 1978: 62 if.), that the verbal style is smoother, more complete and even more personal than the nominal style? Why would he or she do without modal, temporal and numeral indications, all provided for by verbal flexion, and use sterile and sometimes even cumbersome nominalizations instead? Obviously the preference of deverbal nouns over finite verbs is not only or not essentially a matter of style.

Generally speaking the nominal style can be understood as a way of condensing and economizing, which is achieved, however, at the cost of precision and unambiguity ( $c f$. Lüdtke, 1978: 62 ff.).' Besides, frequently used deverbal nouns instead of finite verbs make a text appear more technical and distanced. However, there must be something to the nominal style, otherwise it could easily be avoided.

\footnotetext{
${ }^{1}$ Moirand (1975: 67) says that this kind of economizing and condensing is achieved au détriment de certaines informations et d'une certaine précision. It even lcads to the élimination $[\ldots]$ des circonstants, des compléments et même de l'agent.
} 
It is true that compared to the verbal style, the nominal style seems impersonal, mainly due to the lack of verbal flexion indicating person, number, tense and mode. $^{2}$ This, however, could well be the first desired effect of the nominal style because in this way the text itself seems to claim anonymous but general validity.

A second effect of the nominal style, however, seems to be still more relevant for its use in certain kinds of texts. The comparison of the one exemplary opposition between the two sentences John promised support, but he didn't fulfil the promise versus The promise was not fulfilled, both of which are well-formed, reveals that on the syntactic level the deverbal noun can - in most cases - do without the actants resulting from the specification of the arguments perspectivated by the functor on the logical-semantic level.

The fact that in many cases arguments which are obligatorily realized when governed by a finite verb do not necessarily have to be specified any longer when depending on deverbal nouns might be a sound reason for the preference of deverbal nouns over finite verbs in a number of linguistic situations.

The final point we will just briefly touch upon are the phoric functions of deverbal nouns, endophoric when anaphoric or cataphoric and exophoric when diaphoric.

\section{ACTION VERSUS PROCESS VERSUS STATE}

Deverbal nouns can be investigated from the perspective of the opposition action versus process versus state ( $c f$. Helbig, 1976: $139 \mathrm{ff}$.; 1982: $41 \mathrm{ff}$;; 1992: 158 ff.; Helbig/ Stepanowa, 1978: 179 ff.). Roughly speaking, an action is characterized by a change provoked by an agent, whereas a process represents a change not being provoked by an agent, and we eventually speak about a state if no change whatsoever occurs within the relevant time span. Consequently, an action can be characterized by the features /+agent/ and / + processual/, a process by /-agent/ and /+processual/ and a state by /-agen//and /-processual/ (cf. Stepanowa/Helbig, 1978: 181). Designations of actions are either mono-, bi- or trivalent, the ones of processes are zero- or monovalent, and those of states are either mono- or bivalent.

When looking at the derivational bases of deverbal nouns, it would appear that the verbal bases seem to dispose of the same valency as the nouns derived from them, which means that, e.g. the deverbal noun dance derives from the monovalent verb to dance like in $x$ dances, investigation is based on $x$ investigates $y$ and transmission goes back to $x$ transmits $y$ to $z$. As to the designations of processes, rain, for example, stems from it rains, where it is only the impersonal marker, functioning as the purely syntactic first actant but not as the first argument on the

${ }^{2}$ According to Wells (1966: 217) it is even the main feature of the nominal style that "it helps impersonality". 
logical-semantic level, and evolution can be traced back to $x$ evolves. The same procedure is true of deverbal nouns designating states, so despair stems from $x$ despairs and stay from $x$ stays prep. $y$.

From the pragmatic point-of-view the introductory question Why deverbal nouns rather than finite verbs? literally imposes itself, if the deverbal noun basically perspectivates the same arguments as the finite verb it derives from. The crucial point is, however, that when dealing with the valency of finite verbs, obligatory actants are to be taken into consideration in the first place and only afterwards do facultative actants play a secondary or even peripheral role in the analysis of verbal valency. Only in very few exceptional cases are circonstants required by the verbal functor, like in the above-stated example $x$ stays prep. $y$. In cases like this we qualify adjuncts as obligatory circonstants. The degree of affectedness or even the very being effected distinguishes actants from circonstants, not so, however, the strictly syntactic criterion of being required for a well-formed sentence. Regardless of any specific syntactic functions actants are actors in the broadest sense, whereas circonstants represent the circumstances, as Tesnière ('1965: 102) pointed out in his chef d'ouvre.

In other words, even though the verbal functor perspectivates the same arguments as the nominal functor, like for example transmission analogously to transmit perspectivates a first, a second, and a third argument, there is an important difference between the arguments or actants governed by the verbal or by the nominal functor, respectively. The example of transmission versus transmit clearly illustrates this crucial difference. A sentence like The transmission of the bad news to John shocked everyone is well-formed. Even a sentence like The transmission of the bad news shocked everyone is conceivable, although semantically speaking it is not too informative. However, contrary to these examples, there is no way whatsoever, the verbal functor to transmit can be used in unmarked serialization without at least the first and the second argument being specified as agent and patient, respectively. The third argument also tends to be realized as addressee or beneficiary unless it can clearly be gathered from the context. Neither *Transmitted the bad news to John nor *Mary transmitted to John is acceptable. Depending on the context, John transmitted the bad news is however imaginable.

In the following passages it will be shown that arguments, perspectivated by the functor, be it verbal or nominal because on the semantic-logical level that does not make any difference, are often left unspecified in the course of the syntactification of a conceptual structure. Not being specified actantially does not mean though, that the respective argument has been deleted. What happens is that in the course of the nominalization of the verb arguments which are originally to be obligatorily realized as actants, need not necessarily be specified any Ionger. ${ }^{3}$ The

${ }^{3}$ Even though Helbig (1976) originally seemed to be convinced that any actant governed by a nominal functor was facultative, he admitted after Sandberg (1979) that there were cases in which arguments depending on nominal functors had to be realized obligatorily. His examples - in German - 
status of the respective actants turns from obligatory into facultative - or actants even turn into circonstants, which obviously comes in handy as a frequently used polito-linguistic tool.

We are going to have a close look at three deverbal nouns now, the first of which is designating an action, the second one a process and the third one a state.

(1) Que el orden económico necesita de grandes mejoras y perfeccionamientos es evidente, y nosotros así lo practicamos; pero a lo que conduce su destrucción lo demuestran de una manera elocuente los veintiocho años de ensayos y miserias comunistas. (Franco, 1945a: 11)

The derivational bases of the deverbal nouns la mejora, el perfeccionamiento and la destrucción are the transitive verbs mejorar, perfeccionar and destruir, respectively. As functors they open up relational positions for agents and for affected patients. The specified affected patient of the three verbs is el orden económico. What remains unknown, though, is who will be the agent, or to put it differently, quién va a mejorar, quién va a perfeccionar el orden económico, or the other way round, who might destroy it, quién lo destruiria. As far as la destrucción is concerned, Franco only vaguely alludes to the communists in general.

(2) [Em todos os domínios onde era livre a nossa acção ajudámos no que pudemos o nacionalismo espanhol e a civilização cristã, directamente ameaçados por doutrinas e regimes que só os que andam à cata de desilusōes esperam converter ou tornar inofensivos; ] [...] enfrentando por toda a parte a incompreensão e cegueira da Europa (onde a Espanha nacional tão poucas amizades contava); [...]. (Salazar, 1939: 148)

By means of the prefix in- the already deverbal noun compreensão has expanded into incompreensão, thereby turning into its antonym. A compreensão is based on the transitive verb compreender, which can either be a mental activity or a process in which the one who understands does not assume the role of the agent but rather the one of the experiencer.

Salazar says that Portugal was confronted with incompreensão on the part of Europe without, however, explicitly stating what it was exactly that Europe did not understand. The second argument of compreender remains unspecified which allows Salazar to blame Europe without having to say for what. His diplomatic way of putting it saves him from being held responsible for any false accusations.

(3) Nuestro Movimiento hizo posible la vuelta a España a su propio ser. (Franco, 1945c: 618)

The substantivized infinitive ${ }^{4}$ el ser for the essence is derived from ser, to be, by means of conversion, i.e. by means of the zero-morpheme. One can say $A$ mi me gusta el ser de España but one cannot say *A mi me gusta que España sea because

were: das Meiden des [...], die Berücksichtigung des [...], das Erblicken des [...], das Feststellen des [...] und das Erzielen des [...] (Helbig, 1982: 44).

${ }^{4}$ Díaz Hormigo (1993: 490) considers the substantivized infinitive a derivación impropia because it is a change in nature without any morphological change. 
this pseudo-phrastic first actant que España sea lacks the predication. If Franco formed his sentence without the nominalized ser, he would have to add a predicative complement, which he obviously does not have to do when resorting to the substantivized infinitive.

What Franco understands by el ser de España remains hidden from the listeners without them probably realizing the semantic incompleteness of the syntactically well-formed sentence.

\section{NOMINA AGENTIS - NOMINA ACTIONIS - NOMINA ACTI}

The most frequent translative used for transferring verbs into the nominal category of nomina agentis is in Spanish and Portuguese the suffix -dor, going back to Latin -or or -tor, respectively ( $c f$. Tesnière, ${ }^{2} 1965$ : 404). In the course of the realization of a nomen agentis the position of the first argument of the verbal basis is absorbed or used up (cf. Motsch, 1999). The opening for the patient or the second argument in the case of transitive verbs, however, remains, even though this does not necessarily mean that it has to be specified. ${ }^{5}$ Particular activities unlike habitual activities usually $d o$ require the specification of the second argument ( $c f$. Motsch, 1999: 154; Helbig/Stepanowa, 1978: 178 ff.). ${ }^{6}$

In the following three passages we will try to shed light upon the respective deverbal nouns from this perspective: The excerpt (4) contains a nomen agentis, (5) a nomen actionis and (6) a nomen acti. $^{7}$

(4) [Caiu finalmente o pano sobre a tragédia que a Europa representou e viveu na sua carne e no seu espírito durante os últimos seis anos. (...)] Tão extensa e profunda foi a tragédia que nem mesmo todos os vencedores - e lembro piedosamente o Presidente Rooscveit puderam sorrir ao claro sol da sua vitória. (Salazar, 1945: 93-94)

${ }^{5}$ Motsch (1999: 152) also points out that arguments have not disappeared from the semanticlogical level cven if they arc not realized on the syntactic lcvel: 1. Die Argumentstellen der semantischen Repräsentation von Verben mit den zugehörigen semantischen Rollen bleiben bei der reinen Nominalisierung erhalten; 2. Notwendigkeit und Art der sprachlichen Realisierung verändern sich mit der Nominalisierung.

${ }^{6}$ Pottier's (1964: 128; ${ }^{2} 1971:$ 84) classification of deverbal nouns according to the criteria virtualité, action en cours and résultat corresponds more or less to the one into nomina agentis, nomina actionis and nomina acti. Nomina agentis refer to Pottier's virtualité, consisting of l'origine, la puissance, l'agent, nomina actionis to what he characterizes by le déroulement and l'action and nomina acti are about le résultal, l'effet. He illustrates this distinction by the opposition producteur - production - produit, corresponding to Spanish productor - producción - producto and Portuguese produtor-produção - produto.

${ }^{7}$ Baron's (1994: 31 ff.) classification of substantifs valentiels, which are the deverbal nouns, consists of three groups. She speaks about nominalisation subjective, nucléaire and objective. As far as her criteria are concerned, this classification reflects Pottier's classification. 
Vencedor is to be traced back to vencer, generally perspectivating an agent as well as a patient, although according to the Dicionário sintáctico de verbos portugueses (Busse, 1994: 402) the patient is to be considered facultative. However, even if the second argument is not specified, on the logical-semantic level $x$ wins $y$ or $x$ wins prep. $y$, and in Portuguese $x$ vence $y$, which means that a second argument is perspectivated.

Using a nomen agentis, Salazar manages to avoid having to specify the agent, since the position of the first argument has been absorbed or used up by this particular kind of nominalization, which allows him to speak about the tragedy of war in a very diplomatic way without having to name whom he personally considers the winners and the losers.

(5) Quería venir cuando tuviéramos los materiales en la mano, las organizaciones hechas; cuando tuviéramos los elementos preparados para la operación quirúrgica que es necesario hacer en las provincias españolas. (Franco, 1945b: 620)

Operar: xopera (a) $y$ is the derivational basis of the nomen actionis operación. It is the local circonstant en las provincias españolas that marks out the realm of validity for the surgical operations to be carried out. However, neither the agent $x$ nor the patient $y$, perspectivated by the verbal functor, as a result of which both of them are also perspectivated by the derived nominal functor on the logical-semantic level, are specified.

Not specifying the agent or the patient in this particular case means withholding from the audience who will be the surgeon as well as who or what will be the patient to undergo the operation by the anonymous doctor. Besides, the listeners do not learn either, what kind of operation or surgery Franco is exactly talking about.

(6) [Quando muito, defendemos o nosso dircito e mostrámos que a vida fácil nunca foi nosso quinhão: isso nos dá direito a falar de paz sem se poder dizer que o fazemos por covardia ou comodidade.] É por conviç̧ão; é por dever. (Salazar, 1939: 145)

A conviç̧ão can be used as nomen actionis or as nomen acti, depending on whether it is the process or the result that is being focussed on. In the example (6) $a$ conviç̧ão is used as a nomem acti based on the passive diathesis ficar convencido or ficar convicto. In the unmarked active diathesis convencer is trivalent governing an agent, a patient and a theme. According to the syntactic program the theme is to be realized as prepositional phrase or as infinitive. ${ }^{8}$

In the passage (6) Salazar claims to be speaking out of conviction. He declares himself and his supporters to be convinced. What he withholds from the listeners though, is what they are convinced of, which is undoubtedly the central argument from the polito-linguistic point-of-view.

${ }^{8}$ The respective syntactic programs are correspondingly $\mathrm{N}-\mathrm{V}-\mathrm{N}_{\text {pessou }}-($ de $\mathrm{N}$ ) or $\mathrm{N}-\mathrm{V}-$ $\mathrm{N}_{\text {pessoai }}$ - a l (Busse, 1994: 131). 


\section{PHORIC FUNCTIONS OF DEVERBAL NOUNS}

Further functions adopted by deverbal nouns as strategic means of discourse are those of anaphora, cataphora and diaphora. Anaphora as backward references and cataphora as forward references function endophorically whereas the essence of diaphora lies in exophoric reference ( $c f$. Moirand, 1975). The referential elements of anaphora and cataphora are to be found within the text as opposed to the ones of diaphora, which are to be found outside the text, somewhere in the larger context.

If a finite verb is either taken up or announced by the corresponding deverbal noun the relation or reference is obvious. However, anaphoric, cataphoric as well as diaphoric references do not necessarily depend on an identical morphological basis of the finite verb and the noun derived from it. If a deverbal noun whose stem is morphologically different from the one of the finite verb it refers to, only takes up or foreshadows the semantic content of that finite verb, we speak of conceptual anaphora, cataphora or diaphora.

In the last three passages we are going to have a look at the different phoric functions of deverbal nouns, at the anaphoric one in example (7), at the cataphoric one in example (8) and eventually at the diaphoric one in example (9).

(7) Estimo que vosotras [las mujeres musulmanas] sóis las que mejor podéis ofrecernos una colaboración sincera en esta obra, colaboración que ha de consistir en que pongáis el máximo entusiasmo en vuestros trabajos y el afán por adquirir las perfecciones de que nosotros queremos rodearos. (Franco, 1938: 66)

Franco is speaking about the high quality of life Spaniards enjoy and promises to see to it that the Muslims will also manage to heighten their standard of living back home - after having fought bravely and after having defended and dedicated themselves to Franco's cause at any cost.

Esta obra refers back to the goals of the Movimiento, some of which have been stated explicitly and some of which have only been got across implicitly by having been alluded to by Franco in the first part of his speech.

The transitive-causative variant of obrar in the sense of to achieve something not only governs a first but also a second actant, usually characterized by the semantic feature /+miraculous/. The intransitive variant of obrar in the sense of to work, however, is usually accompanied by a modal, a temporal or also a local circonstant. Anyways, in the above-cited passage neither the first argument, perspectivated in any case, nor the second argument, perspectivated only under the above-mentioned circumstances, has been realized. Due to the nominalization of obrar, it seems as if this verb could do without agent and patient, but as a matter of fact, on the syntactic level the noun obra can.

This is at least how Franco manages to leave everything open in the sense of not binding or committing himself to anything. 
(8) [A terra está ensopada de sangue e de lágrimas; sofreu-se e sofre-se de mais para que nos entreguemos a ruidosas manifestações de alegria.l Contudo, e embora com os olhos embaciados de lágrimas, um íntimo contentamento de alma é justo e devido. Apontarei, resumidamente, os três motivos seguintes. (Salazar, 1945; 94)

The verb underlying the noun o contentamento is contentar, be it the causative variant $x$ contenta $y$ or the recessive, also called medial variant $x$ contenta-se com alguma coisa. The respective implied phrase programs are $\mathrm{N}_{\text {coisa }}-\mathrm{V}-\mathrm{N}_{\text {pessoa }}$ and $\mathrm{N}_{\text {pessoa }}$ - Vse - com $N$ (Busse 1994, 129). Consequently, the verbal basis of the noun phrase o contentamento de alma is either $x$ contenta a alma or a alma contenta-se com $y$. If the first case applies, the first argument has not been specified, so that it turns out to be impossible for the listener to know who or what will satisfy the soul. If, however, the verbal basis is recessive, it would take an instrumental modifier to be realized circonstantially to disclose how the soul will find satisfaction or how the soul will satisfy itself, so to speak.

Anyhow, um intimo contentamento de alma is cataphoric in that it is referring forward to the announced three good reasons to follow for which in Salazar's opinion the Portuguese soul deserves being satisfied.

(9) Pero esta gran obra de resurgimiento y formación que la Patria necesitaba no podía hacerse a través de los instnumentos fríos y burocráticos que representan los órganos normales de Gobierno [...]. Y por eso y para cso es nuestro Movimiento nacional, estas organizaciones juveniles constituídas por unas formaciones selectas que echaron sobre sus hombros la pesada carga de ser los portadores de este anhelo y de esta esperanza. (Franco, 1945d: 333)

As este anhelo as well as esta esperanza are determined by demonstrative adjectives, the listener is bound to have the impression that there must be a clear textual reference, accounting for the use of the determiners as well as giving away the secret of the semantic contents of these two deverbal nouns. However, even when having a close look at the text, one will have to find out that the search for it has been in vain.

Although el Movimiento is vaguely alluded to as being the carrier of hope, it remains a secret for one thing who may hope and for another what may be hoped for. Neither $\mathrm{x}$ nor $\mathrm{y}$ in $x$ anhela $y$ and $x$ espera $y$ respectively, is specified.

What the listeners have to do in order to somehow grasp what Franco means when putting it the way he is, is go beyond the horizon of this speech, put bits and pieces together in order to get thereby sort of a puzzle or patchwork of Franco's ideology. In this sense both este anhelo and as esta esperanza function as diaphoric references. 


\section{CONCLUSION}

If the nominal style helps impersonality due to the disappearance of verbal flexion, as was pointed out at the beginning, we have seen that there are at least two more pragmatic reasons for a speaker to resort to deverbal nouns rather than to finite verbs: 1 . When using deverbal nouns, on the syntactic level he or she usually does not have to specify the arguments perspectivated on the semantic-logical level any longer which allows him or her to conceal relevant information from the listeners without them necessarily realizing it since the sentences are still wellformed. 2. Deverbal nouns assume endophoric and exophoric functions which may be anaphoric and cataphoric when referring to elements within the text or diaphoric when having an extra-textual reference, which make the text for one thing appear a "coherent whole" ( $c f$. Shopen, 1973) and for another integrate it even into larger contexts.

\section{BIBLIOGRAPHY}

Baron, I. (1994), Les syntagmes nominaux français dans une perspective valentielle, Linguistica, XXXIV, 1, 29-45.

Busse, W. (1994), Dicionário sintáctico de verbos portugueses. Coimbra: Almedina.

Díaz Hormigo, M. T. (1993), Sobre la función temática de los sustantivos deverbales y deadjetivales dentro de la tricotomía texto, expresión textual, esquema oracional, in G. Hilty (cd.), Actes du $X X^{e}$ Congrès International de Linguistique et Philologie Romanes. Tome 1. Tübingen: Francke. 481-492.

Helbig, G. (1976), Zur Valenz verschiedener Wortklassen, Deutsch als Fremdsprache, 13, 131-146.

Helbig, G. (1982), Valenz-Satzglieder-semantische Kasus - Satzmodelle. Leipzig: Verlag Enzyklopädie.

Helbig, G. (1992), Probleme der Valenz- und Kasustheorie. Tübingen: Niemeyer.

Lüdtke, J. (1978), Prädikative Nominalisierungen mit Suffixen im Französischen, Katalanischen und Spanischen. Tübingen: Niemeyer.

Moirand, S. (1975), Le rôte anaphorique de la nominalisation dans la presse écrite, Langue française, $28,60-77$.

Matsch, W. (1999), Zur semantischen Grundlage deverbaler Nomen, in B. Skibitzki and B. Wotjak (eds.), Linguistik und Deutsch als Fremdsprache. Tübingen: Nicmcyer, 149-157.

Pot tier, B. (1964), Vers une sémantique moderne, Travaux de linguistique et de littćrature, J], 1, 107-137.

Pottier, B. $\left({ }^{2} 1971\right)$, Gramática del español. transl. A. Quilis. Madrid: Ediciones Alcala.

Sandberg, B. (1979), Zur Repräsentation, Besetzung und Funktion einiger zentraler Leerstellen bei Substantiven. Kungsbacka: Kungsbacka Tryckeri AB.

Shopen, T. (1973), Ellipsis as Grammatical Indeterminacy, Foundations of Language, 10, 65-77.

Stepanowa M.D. and Helbig G. (1978), Wortarten und das Problem der Valenz in der deutschen Gegenwartssprache. Leipzig: Bibliographisches Institut.

Tesnière, L. $\left({ }^{2} 1965\right)$, Éléments de syntaxe structurale. Paris: Klincksieck.

Wells, R. (1966), Nominal and Verbal Style, in T. A. Sebeok (ed.), Style in Language. Cambridge, Massachusetts: The M.I.T. Press, 213-220. 


\section{SPEECHES}

Franco, F. (1938), Breve discurso a las niñas musulmanas en ocasión de su visita a la España liberada, Editado por la delegación nacional de Falange española tradicionalista y de las JONS. Editado en 1939, Palabras del Caudillo. 19 abril 1937 - 31 diciembre 1938. Madrid: Ediciones $\mathrm{Fe}, 65-66$.

Franco, F. (1945a), La verdad de España, P. Rocamora (ed.), Textos de doctrina política. Palabras y escritos de 1945 a 1950. Editado en 1951. Madrid: Publicaciones españolas, 9-12.

Franco, F. (1945b), Voluntad de hacer, P. Rocamora (ed.), Textos de doctrina política. Palabras y escritos de 1945 a 1950. Editado en 1951. Madrid: Publicaciones españolas, 619-620.

Franco. F. (1945c), La victoria de la fe, P. Rocamora (ed.), Textos de doctrina política. Palabras y escritos de 1945 a 1950. Editado en 1951. Madrid: Publicaciones españolas, 617-618.

Franco, F. (1945d), La obra de educación y formación de la mujer, P. Rocamora (ed.), Textos de doctrina política. Palabras y escritos de 1945 a 1950. Editado en 1951. Madrid: Publicaciones españolas, 333-335.

Salazar, O. (1939), A crise politica europeia e a situação externa de Portugal, O. Salazar (ed.), Discursos e notas politicas III. 1938-1943. Editado en 1959. Coimbra: Coimbra Editora, 137-155.

Salazar, O. (1945), No fim da guerra, O. Salazar (ed.), Discursos e notas politicas IV. 1943.1950. Editado en 1959. Coimbra: Coimbra Editora, 93-98. 